\title{
Implementation of Sustainable Financing in Banking Industry
}

\author{
$1^{\text {st }}$ Yunia Amelia ${ }^{1}$ \\ \{yunia.amelia@feb.unila.ac.id ${ }^{1}$ \}
}

FEB, Universitas Lampung, Soemantri Brojonegoro Street Gedong Meneng, Bandar Lampung City Lampung Province ${ }^{1}$

\begin{abstract}
This study wants to explore how to implement sustainable finance in the financial services industry, given the objectives of sustainable finance. This is will essential for realizing sustainable economic growth while still paying attention to environmental sustainability and the financial services industry, including industries that already have a concept to participate in sustainable development. This research method is a literature study to systematically identify and analyze document documents that contain or relate to problems in the research carried out. The final stage is to find the main concepts based on data to be visualized or presented in the form of data analysis results. Results Until now, few studies in Indonesia have examined sustainable finance implementation in the Financial Services Industry Sector. Many financial industries have not correctly implemented the concept of sustainable development, which has been transformed into the financial services industry sector.
\end{abstract}

Keywords: Implementation, Sustainability, Financing, Banking

\section{Introduction}

The financial services industry has an important role to play in a sustainable financing system. The critical role of the financial services industry, especially in the banking sector, in supporting the development process, has made the financial services industry feel challenged by new problems that have become public demands due to the declining quality of conditions and capacity for life. This situation is coupled with the existence of climate change as the impact of development that relies on fossil energy in every business/industry; such conditions lead to demands from the global community to improve welfare not only based on economic value but also thinking about environmental values for the effectiveness of implementing sustainable development. The existence of synergy between the business world, society, and the government to continuously build and create a more prosperous community life and the environment will determine national development [1].

Specifically, the response to sustainable development implemented in the financial services industry has been embodied in a sustainable financial roadmap. This roadmap contains an explanation of a work plan for a sustainable financial program for the financial services industry under the authority of the OJK, namely banking, capital market, and IKNB. his sustainable finance roadmap will become part of the Indonesian Financial Services Sector Master Plan (MPSJKI) and be used as a reference for other sustainable finance stakeholders.[2].

Based on the preliminary pre-survey results, it is known that there are still many financial industries that have not adequately implemented the concept of sustainable development, 
which has been transformed into the financial services industry sector. Until now, there are not many studies in Indonesia that have examined the implementation of sustainability financing in the Financial Services Industry Sector; this study wants to explore further how the effectiveness of implementing sustainable financing in the financial services industry. Research Problems How is the implementation of sustainable financing in the financial services industry? This research was conducted to find out more about what should be done as a step towards improvement in the future, considering that the goal of sustainable financing is fundamental to realize sustainable economic growth while still paying attention to environmental sustainability and the financial services industry, including industries that already have a concept to participate. in the concept of sustainable development. This study's target findings are to find out how to implement sustainable financing in the banking industry. A fundamental contribution to science: This research is expected to contribute to developing concepts and theories related to financial and environmental performance. This research is also expected to have implications for policymakers in drafting regulations and evaluating an ongoing program. For example, for the banking sector and financial institutions, this study's results can measure how sustainable financing is implemented in the financial services industry sector in Indonesia.

Companies or organizations disclose their sustainability activities through sustainability reports. Global Reporting Initiatives (GRI) is a sustainability reporting guideline used by most companies or organizations worldwide. Eight banks published and discloses a sustainability reports in the banking industry, namely Bank BNI, Bank BTN, Bank Mandiri, Bank BRI, Bank Danamon, Bank Jatim, Bank Permata, and Bank Maybank. The Financial Services Authority (OJK), as the financial services supervisor, issued a Sustainable Finance Roadmap in Indonesia; this is part of the Master Plan for the Financial Services Sector in Indonesia (MPSJKI), which discusses sustainable development in the banking industry [3]. The research results using content analysis using secondary data from various bank websites show that the level of sustainable finance disclosure in banks in Indonesia is still low (Ashari, 2018). Other research results show that the Sustainability Report does not affect banking companies' financial performance [4].

The Indian banking sector findings indicate that implementing a sustainable international code of ethics is still early. The results of this study also show that the sustainability issues that are the highest priority for banks are directly related to their business operations such as financial inclusion, financial literacy, and energy efficiency, and banks are more focused on handling the social dimensions of sustainability in banking rather than essential dimensions. Sustainable banking, namely environmental management, development of green products and services, and sustainability reporting. The practical implications of implementing the proposed framework reflect the status quo of sustainable banking in India. This study is useful for banks and all stakeholders to understand better the shortcomings in integrating sustainability issues in banking [5].

The evidence suggests that at present, sustainability initiatives of banks are not central to the business strategy and organizational culture. The evidence in this survey supports the conclusion of the UNEP Inquiry final report The Financial System We Need that "The emerging revolution, however, is incomplete. Developed countries' financial systems are adaptive and highly innovative in some respects, but continue to trend towards greater levels of "financialization," where financial returns increasingly arise from transactions that are disconnected from long-term value creation in the real economy [6]. Based on a systematic review of identified journal articles and books, it is found that currently, sustainable finance research is concentrated in four areas, including stakeholder reviews of sustainable 
construction finance and markets, benefits and constraints of financing sustainable construction projects, identification of financial vehicles for sustainable construction, and innovative models and mechanisms for financing sustainable construction projects [7].

\section{Literature review}

Sustainability is a concept that aims to create a balance between dimensions of development, such as economic, social, and environmental. Moreover, where the development process has a principle that meets the present's needs without sacrificing future generations' needs. The concept of Sustainable Sustainable development (sustainable development) has two key concepts: Need, namely, awareness of the poor's needs in developing countries. Limitations are the limitations of technology and social organization related to the capacity of the environment to meet present and future generations' needs.

Scope of Policy for Sustainable Development Sustainable development includes three policy areas where these policies are interconnected with one another and are a driving force for sustainable development; these policies have policies on economic development, social development, and environmental protection. In the financial aspect, sustainable development is related to economic growth and looks for ways to advance the economy in the long term without spending natural capital.

In the social aspect, sustainable development focuses on humans in terms of interrelation, interaction, and interdependence. It is closely related to cultural elements. Sustainable development aims to maintain the community's cultural sustainability to continue to live a peaceful life. Meanwhile, in the environmental aspect, sustainable development or sustainable development is related to environmental protection, where the development carried out must always involve environmental aspects so that the rapid development does not necessarily destroy environmental sustainability.

Financial Services is a term used to refer to services provided by the financial industry. Financial services used to refer to organizations that handle the management of Bank Funds, Investment Banks, Insurance Companies, credit card companies, consumer finance companies, and securities.[8] Banks are o to adjust the indicators disclosed with the criteria that must be identify reported following GRI. Banks advised to disclose a sustainability report according to a core or comprehensive selection; it can improve the quality of the sustainability report.[9] Clarke and Boersma's 2016 research recommends that sustainability performance is necessary for the critical performance indicators and senior executives' remuneration schemes. Regulatory reforms and changes to stock exchange listing rules can provide a framework for enhancing corporate directors' fiduciary duty towards environmental and social responsibility [10].

\section{Methodology and Data Analysis}

In preparing the first literature review, identification, discovery, and analysis of documents containing or related to research problems will be carried out as a general process carried out by researchers to find a theory [11]. First, this study identifies keywords for research topics to find related material, references, and library materials. Read the abstracts of relevant research reports from library sources, journals, books, and proceedings. Make notes on reading results 
by making a literature map of this sequence and relationship of research topics and complete bibliographic references. Make a complete literature summary based on the literature map according to each research variable's order and topic relevance. I was doing literature reviews by arranging thematically based on essential theories and concepts related to research topics and variables. At the end of the literature review, a general view of the research topic based on existing literature is presented. It explains the originality and importance of the research topic to be carried out in comparison with existing literature. Meanwhile, according to Cooper in Creswell, the literature review's purpose is that the literature review has several objectives: to inform readers of other research results related to the research carried out at that time. Linking research with existing literature and filling in gaps in previous studies [11].

\section{Research Result and Discussion}

Construction. The key indicators of sustainability achievement in the financial industry sector that will be measured are firstly the application of business principles that include the value of the company, secondly regarding understanding in several business cases to support sustainable development, and thirdly, receipt management, including; credit, reputation, legal, environmental and social risks. There is communication between clients, employees, and other stakeholders; Transparency and accountability; There are input and suggestions from nongovernmental organizations; Sustainability rating; Information regarding investment funds and shareholders; Sustainable development; business opportunities and challenges.

Sustainability criteria and indicators can deliver sustainable development goals implemented in a business that is oriented towards profit, people, and the planet. Wibowo, D (2005) stated the following are the criteria for economic, social, and environmental sustainability concerning credit risk assessment/provision of financing and investment by the financial services industry[12].

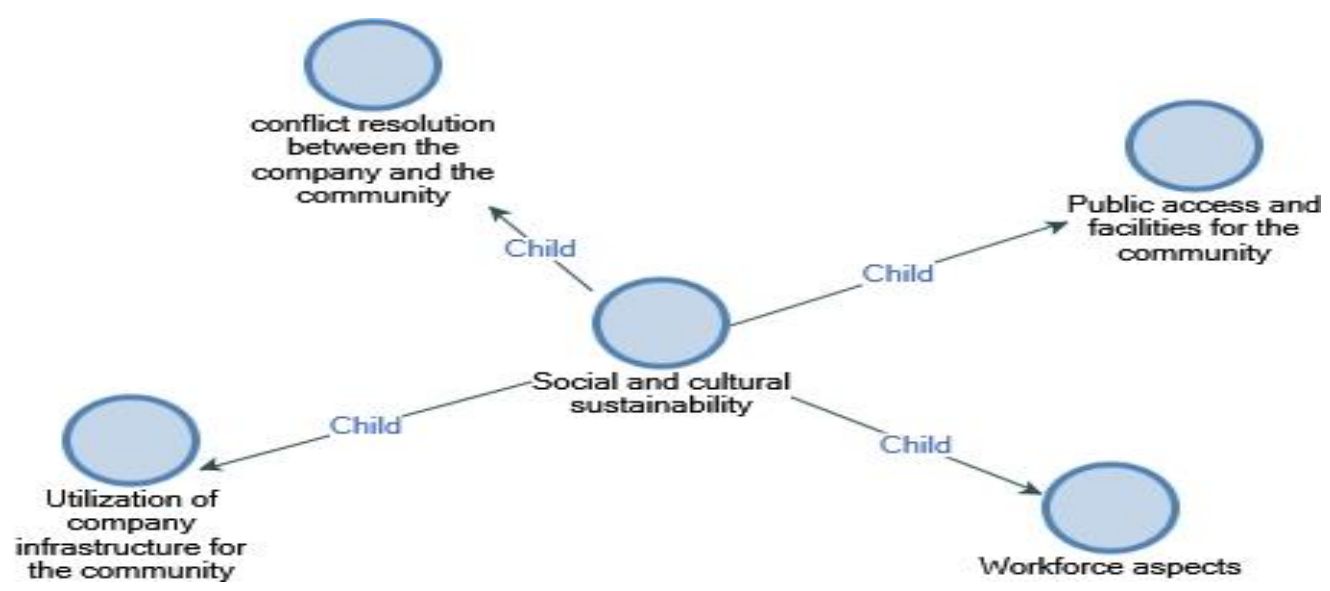

Fig. 1. Social and Cultural Sustainability Indicator 


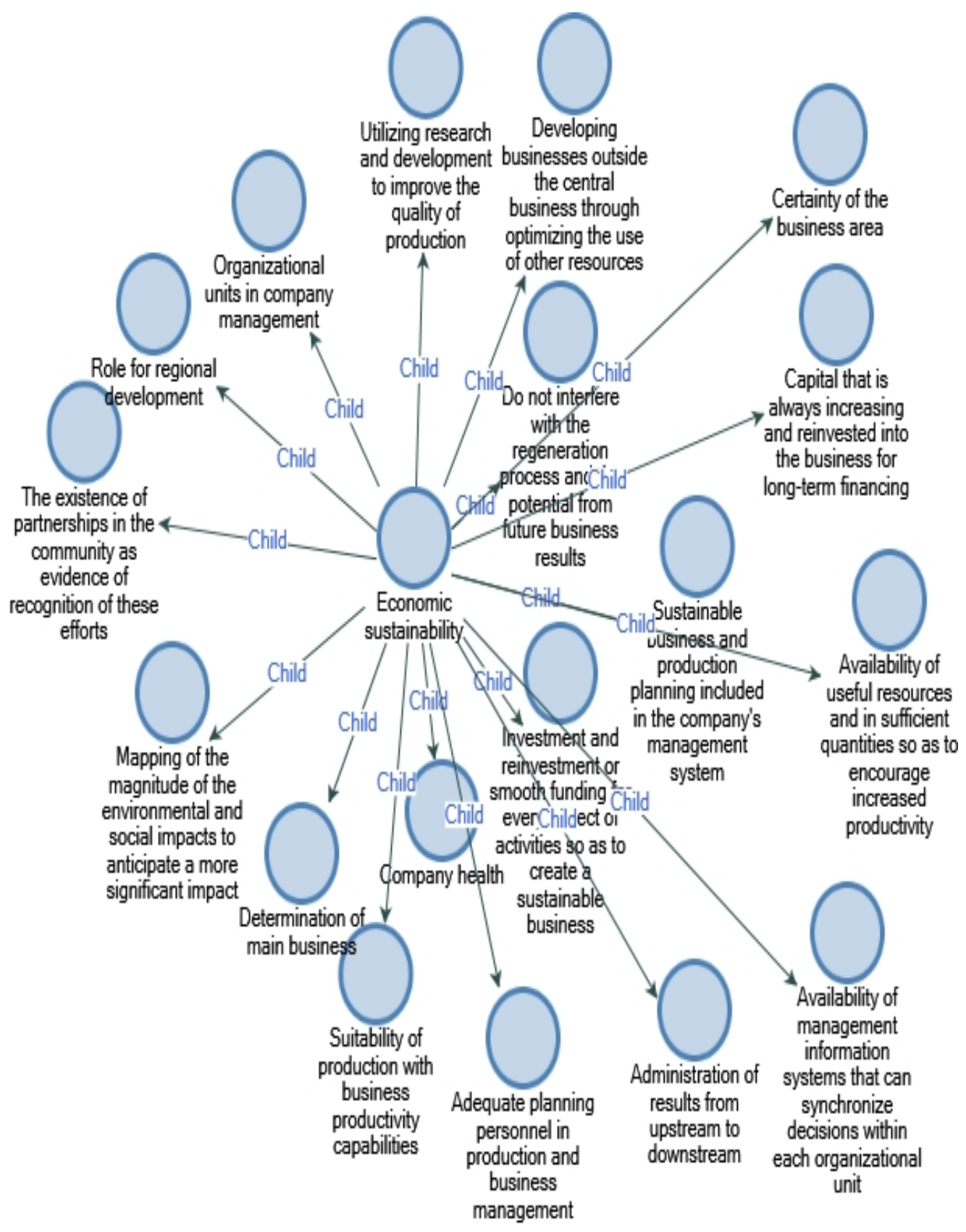

Fig. 2. Economic Sustainability Indicator 


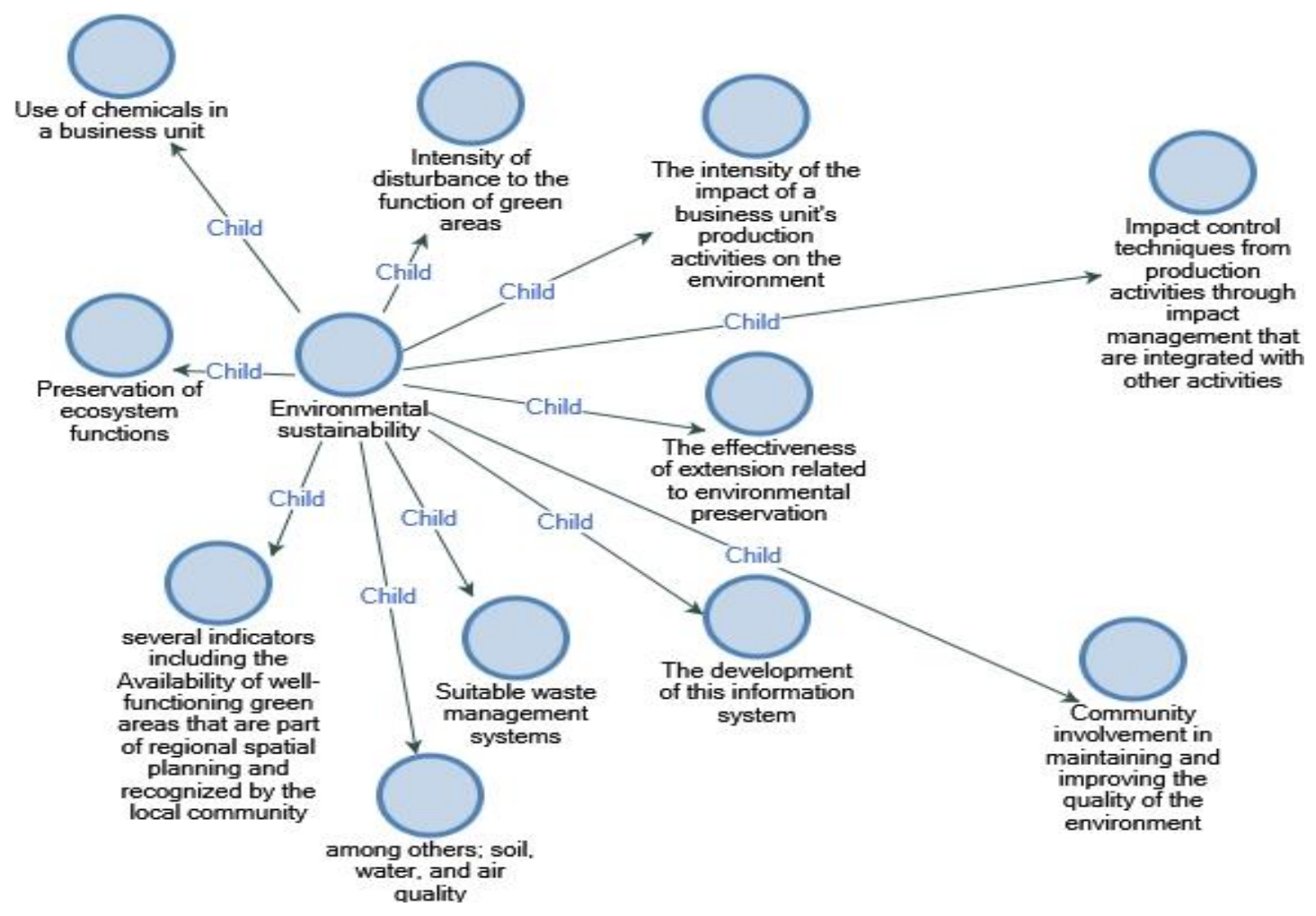

Fig.3. Environmental Sustainability Indicator

\section{Conclusion}

This study's conclusions explain the practical and theoretical benefits, economic benefits, and new findings. Based on the preliminary pre-survey results, it is known that there are still many financial industries that have not adequately implemented the concept of sustainable development, which has been transformed into the financial services industry sector. There are not many studies in Indonesia that have examined the implementation of sustainability financing in the Financial Services Industry Sector.

\section{Implications/Limitations and Suggestions For Further Research}

A study has limitations because only the conceptual method. Further research is needed to see what extent its implementation is sacrificed in banking industry. 
Acknowledgments. The Research Team would like to thank for the Institute Research and Community Service University of Lampung, and the various parties involved in this research.

\section{References}

[1] R. M. Widodo, "Analisis Urgensi Implementasi Corporate Social Responsibility," IQTISHADIA, 2014.

[2] Otoritas Jasa Keuangan, "Roadmap Keuangan Berkelanjutan di Indonesia Roadmap For Sustainable Finance In Indonesia,” 2015.

[3] L. R. Rusdiono, Analisa pengungkapan laporan keberlanjutan dalam rangka menilai kinerja keberlanjutan berdasarkan panduan GRI G4 umum dan GRI panduan khusus layanan .... repository.unpar.ac.id, 2017.

[4] H. L. Sabrina, "Pengaruh Sustainability Report Terhadap Kinerja Keuangan Perusahaan Perbankan," J. Paradig. Akunt., 2019.

[5] K. Kishore and P. Ajai, "Developing a framework for assessing sustainable banking performance of the Indian banking sector," Soc. Responsib. J., vol. 15, no. 5, pp. 689-709, Jan. 2019, doi: 10.1108/SRJ-07-2018-0162.

[6] T. Clarke and M. Boersma, "Sustainable Finance? A Critical Analysis of the Regulation, Policies, Strategies, Implementation and Reporting on Sustainability in International Finance," no. February, p. 33, 2016, doi: 10.13140/RG.2.1.5111.7840.

[7] M. Shan, B. Hwang, and L. Zhu, "A Global Review of Sustainable Construction Project Financing: Policies , Practices , and Research Efforts," pp. 1-17, 2017, doi: $10.3390 /$ su9122347.

[8] B. R. Bhardwaj and A. Malhotra, "Green Banking Strategies: Sustainability through Corporate Entrepreneurship," Greener J. Bus. Manag. Stud., vol. 3, no. 4, pp. 180-193, 2013, doi: 10.15580/gjbms.2013.4.122412343.

[9] I. Ari, "Sustainable Financing for Sustainable Development: Agent-Based Modeling of Alternative Financing Models for Clean Energy Investments,” 2019, doi: 10.3390/su11071967.

[10] A. W. H. Yip and N. M. P. Bocken, "Sustainable business model archetypes for the banking industry,” J. Clean. Prod., vol. 174, pp. 150-169, 2018, doi: 10.1016/j.jclepro.2017.10.190.

[11] J. W. Creswell, "Quantitative, Qualitative dan Mixed Methods Approaches Fourth Edition," no. 0274, p. 20, 2014.

[12] Muliaman D.Hadad dan Istiana Maftuchah, Sustainable Financing. Jakarta, 2015. 